\title{
THE EFFECTIVENESS OF NUMBER HEAD TOGETHER (NHT) IN TEACHING READING COMPREHENSION AT TENTH GRADE STUDENTS OF MAN 4 KEDIRI
}

\author{
Hariyati, Lely Setyawati
}

\begin{abstract}
The aim of research is to know the effectiveness of Number Head Together (NHT) in Teaching Reading Comprehension at tenth grade students of MAN 4 Kediri. Quantitative post-test only control group design used the approach to design this research. The subject of the research is tenth grade student of MAN 4 Kediri. The subject were X MIA 1 class as experimental class which consist of 36 students and X MIA 2 class as control class which consist of 36 students. To get data, the researcher use test. The data analyzed by using t- test can be found with SPSS 16.0. The mean score of students' reading comprehension in experimental class belongs to very good category. Its score 83.19. Meanwhile, the mean score in control class belongs to good category with mean score 77.22. The result of statistical computation value of the independent sample t-test is 3.050 with t table within degree of freedom (df) 70 at $5 \%$ significant level is 2.647 . It can be seen that $\mathrm{t}$-statistic value is higher than t-table. Because there is significant increase in student's reading comprehension after doing treatment, it can be said that number head together in reading comprehension of the tenth grade students of MAN 4 Kediri in academic year 2018/2019 is effective. So the alternative hypothesis was accepted.
\end{abstract}

Key Words: Number Head Together (NHT), teaching reading comprehension

\section{INTRODUCTION}

Reading is one of four important skills in English. Reading is regarded as a decoding skill that is, interpreting codes into ideas. According to Wallace (1996), reading is interpreting, which means reacting to a written text as a piece of communication. In other words, we assume some communicative intents on the writer's part in which the reader has some purposes in attempting to understand. According to Harmer (1996), reading is an exercise dominated by the eyes and the brain. The eyes receive messages and the brain then has to work out the significance of these messages. It means that reading is a process transferring Information from the text then our brain process it and conclude what the text tells about.

Although reading is one of the ways to increase knowledge and to practice language. Teaching reading is related to the other language skills and language components such as vocabulary and grammar but in teaching reading the main focus is on how to make students understand the text. Many students of MAN 4 Kediri who still did not understand and comprehend the English text. Based on the 
observation, there are some problems that affect the students of MAN 4 Kediri in understanding the reading text.

Students got difficult to understand the information in the reading text. The students were confused when the teacher asked them a set of reading comprehension questions for example: Where did they go? What does the word "they" in line 1 refer to? Who was on vacation? Those questions for some students were easy to answer, but for some others were not. So, some of them did not know to answer those questions based on information of the text. Next, students' mastery of English vocabulary is one of the students' problem in comprehend English reading text. And the last is the way of teaching reading. Cooperative learning contributes to high levels of motivation is in the pro academic attitudes that it fosters among group members. Several types of cooperative learning are Jigsaw, Number Head Together (NHT), Think-Pair-Share and Picture, Problem Solving, and teaching game team. Number Head Together firstly designed by Spenser Kagan (2007) He states that "Number Head Together (NHT) involves more students analyze materials in a lesson and check their understanding of the content the materials about".

Number Head Together $(\mathrm{NTH})$ is one strategy which is necessary to help the students to increase their achievement in doing reading comprehension narrative text. This research addressed the following research questions based on the background.

1. How is students' achievement in reading comprehension which is taught by using Number Head Together (NHT) at tenth grade students of MAN 4 Kediri?

2. How is students' achievement in reading comprehension which is not taught by using Number Head Together (NHT) at tenth grade students of MAN 4 Kediri?

3. Is there any significance difference of students' achievement in reading comprehension which is taught and not taught by using Number Head Together (NHT) at tenth grade students of MAN 4 Kediri?

4. Is Number Head Together (NHT) effective to be used to teach reading comprehension at tenth grade students of MAN 4 Kediri?

\section{METHODS}

The design that used in this research is a quantitative approach. The method of this research is effectiveness. Meanwhile, the research design selected was Posttest- Only Control-Group Design. This research was conducted in MAN 4 Kediri, it is located on Jl. Melati no 14 Badas Kediri. This research used two classes which were randomly chosen; they were control class and experimental class. Some procedures of this research, those are: (1) choosing two class as a subject the researcher, (2) giving treatment, (3) giving test to know reading comprehension in narrative text, (4) scoring the result of the test, (5) analyzing the score of the test, (6) discussing of research finding. In collecting the data, test, questionnaire, and documentation were used as the instruments.

The instrument used in this research was multiple choice test, questionnaire and documentation. The test administered for control and the experimental class 
was the same. The test used in this research is post-test only. Post-test was given at the last of meeting after teaching reading comprehension narrative text. The test consist of 20 multiple choice include 3 text that is the legend of Wayang Mountain, Sura and Baya, and Malin Kundang, with 60 minutes. Each item of the test had five options A, B, C, D, and E. Indicators of reading comprehension narrative text such as the definition of narrative text, find the generic structure of a narrative text, find past tense of the text, find the purposes of narrative text, find the general information of the text, find the certain information of the text, specific information of the text, identifying the reference word, identifying antonym or synonym of word. If the answer was wrong, the score was " 0 ". If the answer right, the score was " 1 ". The score of students' test analyzed by using SPSS 16.0 version. Instrument was tried out to MIA 3 with 33 students. Before the instrument were tested to experimental and control groups. It was done to find out the instrument quality, they were; its validity and its reliability.

Questionnaire was conducted for knowing the condition or response of the students whether they had change before and after taught by Number Head Together (NHT) in learning reading comprehension narrative text. The questionnaire for reading comprehension narrative text consisted of 9 which referred to the way of teaching reading, mastery vocabulary, understanding of material and which measured by "Yes" and "No" choices. The questionnaire was given after experimental class was taught by using Number head Together (NHT) a last meeting exactly after post-test.

Documentation was also used in this research. Hopkins (1993:140) stated that document surrounding curriculum or other educational concern can illumine rationale and purpose in interesting ways. Documentation is any communicable material, such as text, picture and video. In this research, the researcher document anything which related to the research, such as documenting the student's score in post-test, the students work reading comprehension narrative text.

\section{FINDING AND DISCUSSION}

After the treatment was given to the experimental class that which is taught by using Number Head Together; while the control class which is not taught by using Number Head Together, then the researcher conducted the post-test. From the post-test it was found the scores of experimental class and control class. The score of test were used to investigate the significance between the experimental and control classes. The result of the test were statistically analyzed by using Independent sample T-test to investigate whether the mean difference between experimental and control classes was significance or not using NHT in experimental class. In this research the researcher formulated the alternative hypothesis (ha) that was "there is significant difference on the students' reading comprehension in the tenth grade students of MAN 4 Kediri". The result is shown in table 4.7. The table is presented as follows: 
Table 4.7 Statistic Difference between Experimental and Control Class

\section{Group Statistics}

\begin{tabular}{|cl|l|l|l|l|}
\hline \multirow{2}{*}{ Class } & \multicolumn{2}{|c|}{$\mathrm{N}$} & \multicolumn{1}{c|}{ Mean } & \multicolumn{1}{c|}{$\begin{array}{c}\text { Std. } \\
\text { Deviation }\end{array}$} & \multicolumn{1}{c|}{$\begin{array}{c}\text { Std. Error } \\
\text { Mean }\end{array}$} \\
\hline \multirow{2}{*}{ Post Test } & Experimental & 36 & 83.19 & 8.548 & 1.425 \\
& Control & 36 & 77.22 & 8.057 & 1.343 \\
\hline
\end{tabular}

Table 4.7 reveals a difference in mean value between the experimental class $(\mathrm{M}=83.83 .19, \mathrm{SD}=8.548)$ and the control class $(\mathrm{M}=77.22, \mathrm{SD}=8.057)$. In order to examine whether the experimental and the control class differed significantly in the test achievement, an independent-samples t-test was conducted using an alpha level of 0.05 The result is indicated in table 4.8

Table 4.8 Independent Sample T-test Result

\section{Independent Samples Test}

\begin{tabular}{|c|c|c|c|c|c|c|c|c|c|c|}
\hline & \multicolumn{2}{|c|}{$\begin{array}{c}\text { Levene's Test for } \\
\text { Equality of } \\
\text { Variances }\end{array}$} & \multicolumn{7}{|c|}{ t-test for Equality of Means } \\
\hline & & \multirow[t]{2}{*}{$\mathrm{F}$} & \multirow[t]{2}{*}{ Sig. } & \multirow[t]{2}{*}{$\mathrm{t}$} & \multirow[t]{2}{*}{ Df } & \multirow[t]{2}{*}{$\begin{array}{l}\text { Sig. (2- } \\
\text { tailed) }\end{array}$} & \multirow[t]{2}{*}{$\begin{array}{c}\text { Mean } \\
\text { Difference }\end{array}$} & \multirow[t]{2}{*}{$\begin{array}{l}\text { Std. Error } \\
\text { Difference }\end{array}$} & \multicolumn{2}{|c|}{$\begin{array}{c}95 \% \\
\text { Confidence } \\
\text { Interval of the } \\
\text { Difference }\end{array}$} \\
\hline & & & & & & & & & Lower & Upper \\
\hline $\begin{array}{l}\text { Post } \\
\text { Test }\end{array}$ & $\begin{array}{l}\text { Equal } \\
\text { variances } \\
\text { assumed } \\
\text { Equal } \\
\text { variances } \\
\text { not } \\
\text { assumed }\end{array}$ & .270 & .605 & $\begin{array}{l}3.050 \\
3.050\end{array}$ & $\begin{array}{l}70 \\
69.756\end{array}$ & $\begin{array}{l}.003 \\
.003\end{array}$ & 5.972 & 1.958 & $\begin{array}{l}2.067 \\
2.067\end{array}$ & 9.877 \\
\hline
\end{tabular}

The interpretation of the table above is; there is significant difference between two classes if sig. (2-tailed) value is the same as or is lower than $5 \%$ or 0.05 . From table 4.8 , it can be seen that the experimental class outperformed the control class in reading narrative text with $\mathrm{t}=3.050, d f=70$ and $\mathrm{P}=.003$ and 95\% confidence interval ranging from 2.067 to 9.877 . From the sig. (2-tailed) we can see the $\mathrm{P}$ is lower than $5 \%(0.03<0.05)$. So, it can be conclude that the $\mathrm{t}-$ value is significant in $5 \%$ significant level. It means that there is significant difference between experimental and control class.

From the above analysis, it was known that there was a different result of students' reading comprehension skill in experimental class are taught by using number head together and control class which is not used number head together. 
The result shows that the mean of experimental class is 83.19 whereas the mean of control class is 77.22. Meanwhile, the standard deviation values of both class are 8.548 and 8.057. These result indicate that the significant different of mean value between the control class and experimental class was found.

A research related to the use of Number Head Together (NHT) in language teaching was done by Meriana YuliAstuti (2014) entitled "The Effectiveness of Numbered Heads Together Technique (NHT) on Students' Reading Ability" the mean of pre-test in controlled class 59.36 is higher than pre-test in experimental class 54.74. Whereas mean of post-test in controlled class 64.48 is lower than in experimental class 68.33. The result is there is a significant progress in using numbered heads technique in improving students' reading ability.

From the result based on calculation of t-test, it is known that t-test result is 3.050 and the significance level 5\% in degree freedom 70 at 5\% significant level (2.647). It means that t-test (3.050) is higher than the critical value (2.647).

From explanation above it can be concluded that Alternative Hypothesis (Ha) is accepted. Alternative Hypothesis (Ha) states: Number head together is effective to be used in teaching reading comprehension at the tenth grade of MAN 4 Kediri. Before testing this hypothesis, t-test is calculated to compare the means between the experimental and control classes. The result reveals that experimental classes outperformed the control classes with significance value $0.3 \%$ or 0.003 as indicated in table 4.8 .

Significance value (sig. 2-tailed) $0.3 \%$ or 0.003 is lower than alpha level of $5 \%$ or 0.05 . The significant different between both class is found. Therefore, the Null Hypothesis is rejected in favor of the Alternative Hypothesis. Thus, Number Head Together is effective to be used in teaching reading narrative text at tenth grade student' of MAN 4 Kediri.

\section{CONCLUSION}

After analyzing the data in chapter IV, the conclusions could take conclusion as follow:

1. The students' reading comprehension achievement which is taught by using Number Head Together at tenth grade students' of MAN 4 Kediri is in very good category with the mean score 83.19.

2. The students' reading comprehension achievement which is not taught by Number Head Together (NHT) at the tenth grade students' of MAN 4 Kediri is in good category with the mean score 77.22.

3. There is significance difference between teaching reading comprehension which is taught and not taught by using Number Head Together (NHT). The result shows that teaching reading narrative text which is taught by using $N H T$ is higher than teaching reading narrative text which is not taught by using NHT. It is also proven by the result of independent-sample t-test which values of sig. 2-tailed is $0.003(\mathrm{P}, 0.05)$.

4. Number Head Together (NHT) is effective to be used in language teaching especially in teaching reading comprehension. It is proven by the result of t-test $3.050>2.647$ ) so, the t-test is significant in $5 \%$ significant level. 


\section{BIBLIOGRAPHY}

Brown, D., (2004). Language Assessment: Principles and Classroom Practice. San Fransisco State University: Longman.

David Hopkins (1993). A Teachers Guide to Classroom Research. Philadelphia. Open University Press.

Fauziati, Endang. 2012. Teaching of English as a Foreign Language. Surakarta: Muhammadiyah University Press

Grabe, William., Stoller, Freadicka L. 2002. Teaching and Researching Reading. England: Longman

Harmer, J. 1996. The Practice of English Language Teaching-New ed. New York: Longman Publishing.

Huda, M. 2011. Cooperative Learning: Metode, Teknik, Struktur dan Model Penerapan. Yogyakarta: Pustaka Pelajar.

Iskandar. 2014. Reading in the Beginning and Intermediate Collage Foreign Language class. Washington, D.C: Georgetown University.

Kagan. (2007). Number Head Together (NHT). Tersedia: http://www.eazhull.org.uk/nlc/number_heads.htm. [10 April 2019].

Wallance, Catherine. 1996. Reading. New York: Oxford University Press. 